\title{
The role of public education in governance for resilience in a rapidly changing Arctic
}

\author{
Douglas S. Cost ${ }^{1}$
}

\begin{abstract}
Education and learning possess powerful potential in affecting future resilience and sustainable states. Here, I focus on unpacking and examining the connections and feedbacks between social-environmental systems (SESs), resilience, and compulsory education. SESs have been problematized as frequently having a poor fit between environmental change and policy solutions. The last few decades have witnessed global recognition of climate change in the Arctic. This has led to discussion and debate over the role of schools in addressing local knowledge, environmental changes, and community priorities. In Alaska, USA, and other Arctic regions, the role of public schools in improving this fit has been largely overlooked. I hypothesize that, as extensions of governments, public schools in the North American Arctic and other locations offer an opportunity to create better linkages between societies and environments through governance. Secondarily, at the individual level, education is a vital component of resilience, but such education must embrace multiple perspectives in its curriculum to honor and access the diversity offered by local and traditional ecological knowledge and Western methods. Lastly, at the societal scale, schools are an untapped resource with which to meet the challenge of bolstering capacity for adaptation in a time of rapid transformation for Arctic societies.
\end{abstract}

Key Words: governance; public education; resilience; rural schools; social-ecological systems

\section{INTRODUCTION}

Given the rapid social and climatic changes occurring in the Arctic (Arctic Governance Project 2010, Lovecraft and Eicken 2011, Arctic Monitoring and Assessment Programme 2012, Arctic Council 2013, Walsh 2013), how do we create better linkages between societies and environments through governance? This question is intimately tied to the power of public schools to inform behaviors, enculturate practices toward environmental systems, and educate students with the knowledge required for decisionmaking: in short, governance. In this special issue, Spellman (2015) discusses elements of learning that are possible in socialecological systems (SESs), but how might these kinds of learning be promoted through governance? In other words, whose hands will wield "learning tools" and to what ends? Here, I examine the public educational system and review its potential as a transformative component of rapidly changing SESs. I argue that the compulsory school systems present in the eight Arctic nations that serve remote locations can be considered "governance agents" in the push toward Arctic resilience. I focus primarily on Alaska, USA, but draw lessons from pertinent northern cases with similar demographics, history, environment, and policy in school systems. Alaska lessons in Arctic resilience via education apply most readily to Canada, but may also apply to northern Scandinavian and Russian systems, although further research is needed.

As systems, school systems are an assemblage of actors, institutions, and infrastructures that form the complex whole of compulsory $\mathrm{K}-12$ education in the USA. As a consequence, they create and maintain various forms of capital (human, social, built, environmental) that alter their social and ecological environments. Broadly speaking, the U.S. public school system acts as an agent of governments at national, regional, state, and local levels. This effect is significant, considering the it includes children and their care providers from approximately ages 5-18 for the majority of any given calendar year. As such, school systems are complex layered policy "action situations" (Ostrom et al. 2014:272) or "policy subsystems" (Jenkins-Smith et al.
2014:189). They are a specific kind of formal learning subsystem within any given SES. Their compulsory nature, enculturation role, and relation to government agendas make them particularly important for the study of connections between learning, governance, and resilience. My aims are threefold. First, I explain how public education is a form of governance. Second, I explain the role of education in resilience. Finally, I propose how schools are, and can better be, a force for individual and community resilience in social-ecological systems across the Arctic. In short, I argue that school systems are agents of governance that can affect an individual's capacity to be resilient in the face of setbacks, and also more widely, a community's capacity to be anticipatory and responsive to changes.

\section{SCHOOLING AS GOVERNANCE DEFINED}

Why should schools be considered agents of governance? Governance is discussed differently depending on the context. According to Lebel et al. (2006:4),

Governance [is] the structures and processes by which societies share power, shape individual and collective actions (Young 1992). Governance includes laws, regulations, discursive debates, negotiation, mediation, conflict resolution, elections, public consultations, protests, and other decision-making processes... It can be formally institutionalized or expressed through subtle norms of interaction or even more indirectly by influencing the agendas and shaping the contexts in which actors contest decisions and determine access to resources.

Schooling and the policies that affect schooling tend to incorporate and include many if not all of this definition of governance. Considered from an SES perspective, "In socialecological systems, diversity is created through experimentation and innovation, and selection occurs through the process of governance - the patterns of interaction among actors that steer social and environmental processes within a particular policy arena," (Kofinas and Chapin 2009:73). Public education fosters 
experimentation and innovation, in both positive and negative directions, and forms methods and patterns through which much human-environmental discourse occurs. Schools form the foundation from which diverse actors begin patterns of interaction with social and environmental systems. These patterns inform how adults conceptualize resilience, individually and collectively. Thus, schools can enhance the diversity among actors, practices, and institutions that can foster opportunities for innovation in SESs. Schools in the Arctic are often in remote locations (i.e., in Alaska, dozens are off the road systems), and many serve a large percentage of Indigenous students. This isolation and service to Indigenous populations make Arctic schools of particular importance and similar in their function to other rural schools. In many cases, rural schools function as physical and psychological meeting grounds (Comber 2013) and community centers (Miller 1995, Salant and Waller 1998, Johns et al. 2000). They host many of the interactions among actors that steer social and environmental processes (Orr 1994, Wright 2007).

More specifically, related to the actors in environmental governance, Lemos and Agrawal (2006:298) state, "Governance is not the same as government. It includes the actions of state and, in addition, encompasses actors such as communities, businesses, and NGOs [nongovernmental organizations]." They further depict the three major actors in environmental governance as the state, market, and community. Thus, co-management can occur between state and community, public-private partnerships between state and market, and private-social partnerships between market and community (Lemos and Agrawal 2006, 2009). Public schools traditionally are dominated by the state and its "regulatory processes, mechanisms and organizations through which political actors influence environmental actions and outcomes" (Lemos and Agrawal 2006:298). Although schools do partner with community and market forces, I focus on them here primarily as a government-driven component of governance, and I ultimately argue that a model approaching co-management between community priorities and government directives may be best for Arctic North American school systems.

Public schools are agents of governance in SESs and are thus capable of being transformative. In the 1900s, scholars began writing about the relationship between schools and social power. Dewey (1897) explained the role public schools play in implementing governing technologies. Their understanding that children reproduce what is taught to them, including sociopolitical roles, and reproduce them as an extension of their home life, is a critical aspect of the political socialization of public schools. Schools begin the governance of children by strangers charged by the state with the responsibility to enculturate and educate children in the social norms of the community (Dewey 1897). This paradigm means that negative or positive reflections of home life (culture, attitude toward nature, class, race, ethnicity) will be addressed directly or indirectly in school and later reproduced by the children. These assertions have been supported by a range of scholars from different fields (Eliot 1959, Greenstein 1960, Patterson 1960, Coleman 1961, Key 1961, Litt 1963). Popkewitz (1998:552) further supports the emphasis that education, curriculum, and pedagogy are extensions of state governance.

\begin{abstract}
The coupling of a stable disciplinary knowledge with the individualization processes of pedagogical knowledge makes the purpose of teaching become the practice of governing children. Teachers assess and administer children's conceptions (or changing misconceptions) of school subjects. The governing principles in the rules of problem-solving structures of the curriculum go unexamined. What is perceived as children participating in their constructions of knowledge is children participating in historically derived systems of reasoning that are themselves the unacknowledged effects of power.
\end{abstract}

Considering school systems within a framework of SESs that addresses governance requires us to consider more deeply the influence of public schooling on shaping the vulnerabilities and adaptive capacities of community members to external drivers such as rapid economic development or climate change (Fig. 1).

Fig. 1. Depiction of school systems within a framework of social-ecological systems that addresses governance. The framework requires deeper consideration of the influence of public schooling on shaping the vulnerabilities and adaptive capacities of community members to external drivers such as rapid economic development or climate change.

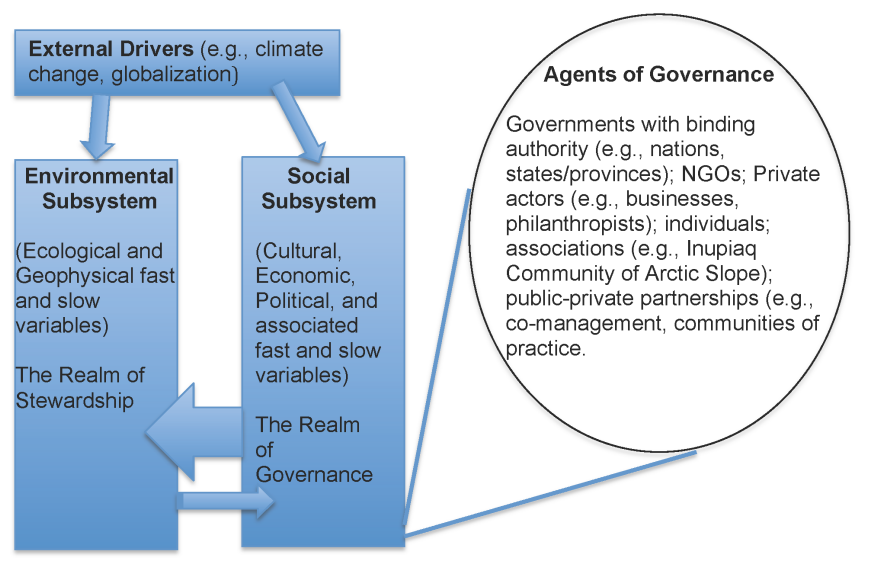

Although generally overlooked in SES analysis, public schooling has been influential in how Arctic communities have been governed. A brief review demonstrates this point. In Alaska, northern Canada, and other Arctic regions, public education was initially often a tool for efforts to subjugate Indigenous populations (e.g., Inuit, Sami) and forcibly govern them through assimilation policies. The introduction of Western schooling in the Arctic was largely a negative influence (Kawagley 1995, Darnell and Hoëm 1996, Todal 1999, Barnhardt 2001, Rasmussen 2001), and many people still perceive Western schooling as a negative influence on communities in spite of efforts at change (Jester 2002). Education systems have been agents of governance by compelling people to attend school, physically relocating people, instructing students on correct social behaviors, eradicating languages, and disconnecting a continued capacity for connection to the land and ecological knowledge. Barnhardt (1981:2) summarizes the negative examples of schools in governance for Indigenous peoples: "Schools were agents of the dominant society and as such, they reflect the underlying cultural 
patterns of that society. As long as they reflect the structure and social organization of the dominant society, they can be expected to perpetuate its values, attitudes, and behavior patterns within an implicit framework of assimilation."

Governments used the public school system simultaneously to govern Indigenous peoples and to disperse their capacity for political power. Furthermore, schools and their policies and curricula often disrupted the capacity of the people to develop, practice, and pass on traditional ecological knowledge (TEK) as well as a vital suite of other traditions, practices, and values. The public school system not only did damage to social sustainability but also disrupted the capacity for the people who had been the main bearers of knowledge about the Arctic environment to pass on their learning and local ecological knowledge to their descendants, thus weakening environmental stewardship practices. For example, language eradication practices are destructive not only to social cohesion and individual identity but also to the repository of environmental wisdom (Maffi 2005, 2007) that could be drawn upon in times of disruption or change. The frequently targeted and systematic efforts to destroy and redirect Indigenous ways of knowing also meant a diminishment of environmental practices and attitudes by people adapted over millennia to live in the far North (Barnhardt 2005, Gerlach et al. 2011). This process, however, did not have entirely negative outcomes, if one considers the necessity for Indigenous people to learn to navigate the new multicultural Western style systems of education, politics, and social-cultural activities that would pervade their lives. Educational practices, as I stress here, enculturate. Many Indigenous activists and leaders of today are able to participate and contribute effectively in both knowledge systems in part due to their Western education.

\section{INEXTRICABLE LINK OF EDUCATION AND RESILIENCE}

Resilience generally refers to the capacity of an individual or community to cope with stress, overcome adversity, and adapt positively to change (Kaplan 2002, Varghese et al. 2006). It is important to consider that education is an ongoing process that equips individuals with the capacity and learning necessary to be resilient in the face of stress, change, or perturbation (Tidball and Krasny 2011). Olsson et al. (2004) argue that because of incomplete data on ecosystems and a perfect state being unachievable, adaptive management, experimentation, and innovation are the keys to successful enhancement of resilience. Diversity and knowledge networks are integral in the problemsolving and critical feedback stages in SES assessment and management. In particular, adaptive management for resilience in a system is information intensive and relies on "functional groups of social memory" (Folke et al. 2002:380). Schools are groups of social memory; the question is how well they function.

Because both local and boarding schools often stripped Indigenous peoples of their traditional education and languages, traditional knowledge and wisdom about the environment and its stewardship were lost. The generational disconnect and physical removals from traditional learning environments were detrimental to the resilience of rural Alaskan communities across many dimensions (Hirshberg and Sharp 2005). Loss in the way of observations, livelihoods on the land, skills in traditional practices, familial and community relationships, and inherent and spiritual connections to land and ocean all contributed to the loss of valuable knowledge passed down through generations of Indigenous peoples (McLean 1997). More recently, McGregor's (2010) work on cultural assimilation in the Canadian context shows the negative effects on families and communities that residential schools had on the necessary skills for survival and learning that previously took place within extended family member arrangements. Responsible behaviors toward the environment were taught in the Inuit traditions through their own system of education. Once the Indigenous educational system was usurped by the national Canadian system, these stewardship themes were passed over and, in the cases of residential school separation, sometimes never taught (McGregor 2010). As noted earlier, education is governance. While I have highlighted the negative aspects to press the point that resilience has been diminished, Western education and knowledge also contributed much to some Indigenous peoples' expertise, work, and impact in their communities and beyond. The education imposed on Indigenous people in the Arctic, for those who navigated the system successfully, has provided them valuable skill sets to function in an altered social-ecological landscape.

When the importance of adaptive capacity to resilience is reviewed (Folke et al. 2002), we must consider current public school practices. Most public school systems tend to focus on static measures of knowledge such as punctuated standardized tests, rather than acknowledge that the process of education itself can cause certain qualities to be present or absent in a person. However, there is a recent movement within educational studies to value what schools can offer individual students in terms of resilience skill sets, which Henderson (2013:25) calls "internal protective factors that foster resilience" (e.g., relationships, selfmotivation, perceptiveness, creativity, perseverance). Education and governance are thought of as separate components promoting resilience, but I argue that public education is governance that has the capacity to create poor or effective stewardship of an environment and thus the vital ecosystem services provided to society (Millennium Ecosystem Assessmnt 2005). Public schools are actors that shape both social and environmental processes in communities through their organizational relationships with other social actors to secure their own ends, i.e., the enculturation of generations of students and engagement in multiple policy areas (e.g., local taxes, food provision in schools, after-school activities). The public school system as a tool of governance can be destructive and detrimental, but it also has the potential to be productive and creative through good governance. If education can lower SES resilience, it can also positively affect resilience. If governance to assimilate and enculturate through schools can produce tragic outcomes, then we can take seriously the proposition that good governance can provide for better social-ecological outcomes. School systems can be a tool for promoting a suite of positive behaviors toward terrestrial and marine systems through shaping attitudes and activities in relation to the natural world. This is most likely when schooling's goals, outcomes, and corresponding assessments can be directly informed by community-level adaptation needs.

In the Arctic and in other locations with school systems that serve rural and Indigenous populations (e.g., New Zealand, Australia), making connections between schools, adaptive capacity, and resilience requires the input of both Indigenous knowledge 
systems and Western scientific methods to produce new generations with adaptive skills. Multiple sources demonstrate the power of TEK to effect environmental stewardship (Gadgil et al. 1993, Berkes et al. 2000, Turner et al. 2000, Hunn et al. 2003). TEK is being used successfully in the co-management of many environmental systems, which leads one to ask: Why would it not be productive in educational systems? Schools are politicized and publicized environments that in rural locations often serve as "the glue that binds together small communities, serving as their economic and social hub" (Jimerson 2006:5). The inclusion of diverse ways of knowing, in particular Indigenous ways of knowing in Arctic communities, can enhance resilience. Education prepares students for uncertainties in SESs as different types of curriculum shape how students learn to problem-solve, value natural capital, and relate environments to economic and cultural systems. There is no uniform definition or plan as to how this would happen from location to location. School personnel need training in the modes of adaptation and resilience locally with TEK and Western science.

Both individual and community-wide results have begun to be cataloged. Benard (1995:2), summarizing a decade of longitudinal studies on factors fostering resilience in children, defined resilience as "a term used to describe a set of qualities that foster a process of successful adaptation and transformation despite risk and adversity." Bergstrom et al. (2003) examined factors that fostered resilience in Native youth from the United States and Canada, and found across 120 interviews, common connections to parents, community, teachers, and schools as major contributors to resilience. In addition, a large majority of the youth cited connection to their culture as a key factor. Groundedness in home culture allowed for confidence in crossing between home culture and school culture. Additionally, participating in a school curriculum that included their Indigenous culture, history, and language was also cited as a source of resilience for these Native youth (Bergstrom et al. 2003). These definitions of resilience are specifically addressing the human in an SES, rather than simply applying a biological concept of resilience to human behaviors. And what else is governance but targeting human behavior? At the community level, Wright's $(2004,2007)$ work in New Zealand and her extensive review of other cases of rural schools have demonstrated the power of such schools to re-energize communities and to serve as social hubs on a community-wide level that can positively affect adults as well as children. Wright (2007:355) notes the "inextricable linking of a school with its community not only allows, but also actively encourages social connectedness... the school's inseparability from its community ensures not just the school's survival, but the community's survival as well."

\section{THE RESILIENCE-GOVERNANCE CONNECTION}

The history and future of government influence on schools is progressing through three "R's": religion, reason, and resilience. In the earliest days of formal public education in North America, schools and curriculum were built around religion-based ideals to provide a moral education for students along with basic subject material. After World War II, the economy became the emphasis of governance in preparing students for future work; this meant their rational faculties had to be brought to the fore, and reason dominated curricula. Given the rapid social and environmental changes at high latitudes, many ask how we might move to the third R: resilience. If learning can enhance resilience at the individual and community levels, then why could schools not consciously be used to teach and learn for resilience outcomes?

Olsson et al. (2004) argue that "successful adaptive approaches for ecosystem management under uncertainty need to (1) build knowledge and understanding of resource and ecosystem dynamics, (2) develop practices that interpret and respond to ecological feedback, and (3) support flexible institutions and organizations and adaptive management processes." Public schools are a source of each of these aspects. First, schools are part of a process of governance that teaches; provides learning, experimentation, and experience to people; and creates a store of problem-solving knowledge from which to draw (e.g., production of citizens, enculturation of ideas about nature). Second, schools create learning and experiences that promote or prevent the understanding of students in relation to activities based in dynamic ecological knowledge (e.g., keeping kids out of hunting or allowing flexible schedules for whaling), and they can serve as institutions that adapt to a constantly changing environment. Third, the provision of education can create informed and thoughtful people who can formulate coping strategies. This requires both attention to solving the problems facing schools across North America (e.g., keeping students in schools, the fact that males are falling behind) and actively collaborating with local communities to create place-based curriculum. It is this combination of knowledge, environmental subjectivity, and flexibility that can prepare students for uncertainties that may arise in SESs.

Lebel et al. (2006:1) note three attributes of governance that function in society to enhance the capacity to manage for resilience: "(1) participation builds trust, and deliberation leads to the shared understanding needed to mobilize and self-organize; (2) polycentric and multilayered institutions improve the fit between knowledge, action, and social-ecological contexts in ways that allow societies to respond more adaptively at appropriate levels; and (3) accountable authorities that also pursue just distributions of benefits and involuntary risks enhance the adaptive capacity of vulnerable groups and society as a whole."

Public schools encourage diverse participation in that they purport to be all-inclusive, especially in the context of remote rural schools where there is generally no alternative. Schools can be sites for deliberation and are currently a passive part of resilience because of the trust, participation, and communication inherent in the school system. A school system itself is a polycentric and multi-layered organizational system in its multiple classrooms and different learning environments. School systems also engage multiple levels of governance as hosts and participants. These relationships have the capacity within many of the negotiations transacted in the SES to affect formal and informal rules. Empowering local school boards, community members, and stakeholders to hire leaders and teachers who are willing to enact a combined vision of local and global priorities ensures a level of accountability and justice that can increase the resilience of schools systems and SESs. Public schools do or can meet these criteria, although the role is often not formally recognized. They have a direct hand in the development and enhancement of well-being and the diversity of coping strategies within a community, and can capitalize on the enthusiasm of the community's youth to be integral players in the process. 
Two suites of requirements for resilient outcomes can be used to build governance factors that foster resilience with a school system (Fig. 2). These six key variables within a school system can result in higher or lower resilience in its SES.

Fig. 2. Two suites of requirements for resilient outcomes can be used to build governance factors that foster resilience with a school system. These six key variables within a school system can result in higher or lower resilience in its socialenvironmental system.

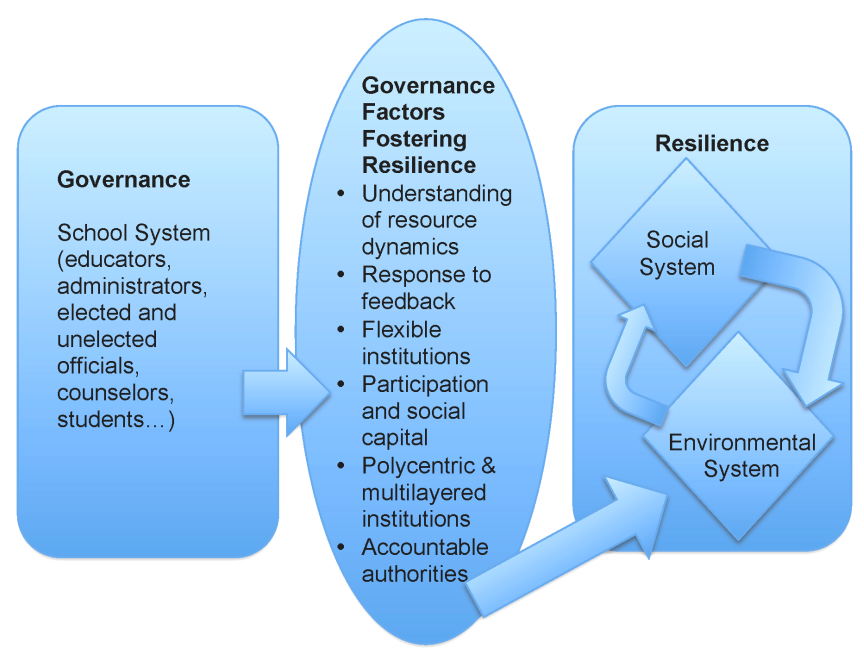

\section{DESIGNING SYSTEMS FOR NORTHERN ADAPTATION}

In using the resilience concept for school systems, it is necessary to be aware that many school systems have also been resilient in negative ways (i.e., maladaptive) due to traditional reiterations of hegemonic hierarchical systems, retention of poor teachers, and inflexible standards. Such ossification in a system can spill over into communities, resulting in students less likely to navigate their life paths effectively. Consequently, school systems must be positively adaptive to foster resilience. Dewey (1897:8) states,

I believe that education is the fundamental method of
social progress and reform. ...much of present education
fails because it neglects this fundamental principle of the
school as a form of community life. It conceives the school
as a place where certain information is to be given, where
certain lessons are to be learned, or where certain habits
are to be formed. The value of these is conceived as lying
largely in the remotefuture; the childmust do these things
for the sake of something else he is to do; they are mere
preparation. As a result they do not become a part of the
life experience of the child and so are not truly educative.

This statement, made more than one century ago, captures the essence of the disconnect for students, who are also future stewards of the Earth and its processes. Without the connection to community life, culture, and traditional knowledge, the value of what is being imparted to students in the classroom has the potential to be lost on them. The future, and its necessary skill sets that are standardized by state and federal priorities for schools, is often an unlikely future in the context of remote rural Arctic locations.
Through incorporating place-based and culturally identifiable aspects in school, education could create connective life experiences for students. How can this form of education be incorporated into governance? Traditional ecological knowledge (TEK), local knowledge, and place-based learning programs have all been demonstrated to foster resilience to an extent. In Indigenous knowledge systems, TEK is thought of as a cultural process, whereas Western education is often thought of less as a cultural process and more as "neutral" learning, even as it enculturates. Both forms of education teach approaches toward nature. Language preservation efforts in Alaska and Canada are also forms of place-based and land-connected learning (Raffan 1993, Krupnik and Jolly 2002, Semken 2005).

Bohensky and Maru (2011) surveyed a decade of literature specifically addressing the integration of Indigenous and Western knowledge. They argue that although there are many efforts, and a valid theoretical basis, for the integration of TEK and Western science, there is a lack of strong empirical data showing their productivity for enhancing resilience. However, they note that resilience stresses the need for "novelty and innovation in human interactions with the world, based on different knowledge systems" (Bohensky and Maru 2011:11). Novelty and innovation are key elements in the process of knowledge integration; these are also foundational to resilience, as "knowledge identities are maintained, but enriched through interaction with one another" (Bohensky and Maru 2011:11). In sum, there is currently limited evidence demonstrating that the integration of knowledge systems causes social-ecological resilience, but the data do support that the process of integrating knowledge systems enhances an individual's skill sets. These skill sets can feed into community resilience. In fact, simply grappling with two different knowledge sets has value (Seidman 1986, Kawagley and Barnhardt 1999).

Place-based schooling, while touted for its goodness of fit for environmental awareness (Gruenewald 2003, Sobel 2005) is not often discussed as a tool of resilience, although it can be one. Wright $(2007: 348)$ notes that communities "must be resilient to be sustainable. Resilience results as relationships among community members develop." In this sense, all place-based education promotes better understanding of one's community and one's SES, and resists the mono-cultural tendencies of standardized education that often have negative effects on Indigenous youth (Jester 2002). "By using the local ecological and socio-cultural setting as the organizing focus, place-based education aims to re-establish connections among schools, youth, and communities that have disintegrated in conventional schooling" (Wright 2007:256). Place-based schooling and local influence or control over schooling are both constructs that better inform education, curriculum, and programs to prepare students to be self-sufficient, resilient, and personally fulfilled individuals who are contributing to the SES. Wamsler et al.'s (2012) research shows increased resilience from increased local education in Brazil and El Salvador. Those living in the lower socioeconomic status enclaves of two case-study cities, and in schools focused more on the community, were better prepared to be resilient in the face of environmental catastrophe. Furthermore, the respondents with more years of formal education were better equipped with the skills to interface with organizations that facilitated resilience, and this additionally prepared them to speak more easily with authorities like the police or medical personnel (Wamsler et al. 
2012). Schooling, both of the place-based kind that is the usual suspect for SES resilience, but also simply more education, is correlated with resilience.

Nicol et al. (2013) profile a program on the Pacific Northwest coast of British Columbia, Canada, that relies on teacher innovation and collaboration to find more culturally responsive education (CRE) pathways to teach math to students who were struggling. CRE required the following of its teachers and students: inquiry-based critical thinking, valuing diversity in thinking, understanding and problem solving, and a requisite of social consciousness and personal and collective agency. The teachers used place, culture, and connection from which to build math curricula and lessons. These methods demonstrated that the experiences, knowledge, and culture that students brought to the classroom were valuable and valued. The verdict is still undecided because studies on CRE conflict as to contributions to educational outcomes. The difficulty lies in the fact that standardized government assessment measures often do not assess aspects such as cultural, personal, or Indigenous resilience, but rather the discrete set of skills set forth in the test instrument. A resilient ecosystem relies on resilience-minded actors who think critically and solve problems in a particular ecosystem context; this is generally not what standardized assessments measure.

\section{POTENTIAL CAPACITY OF EDUCATION TO AFFECT RESILIENCE}

School as a form of governance has often been detrimental to those peoples who have been marginalized and colonized. How, when thinking about school as a form of governance, can it be transformed to better fit the needs of those it serves and continue to govern? Richard Shaull (1970:6) reflects in the Foreword to Paulo Freire's Pedagogy of the Oppressed,

\begin{abstract}
There is no such thing as a neutral education process. Education either functions as an instrument that is used to facilitate the integration of the younger generation into the logic of the present system and bring about conformity to it, or it becomes the 'practice of freedom', the means by which the men and women deal critically and creatively with reality and discover how to participate in the transformation of their world... For those who are committed to that task and are searching for concepts and tools for experimentation, Paulo Freire's thought will make a significant contribution in the years ahead.
\end{abstract}

Presently, public education in the U.S. and Canadian High North has ameliorated some of the worst aspects from the boarding school and Indigenous language extinguishment period, with novel and increasingly effective efforts to include Indigenous ways of knowing in classrooms (Lipka et al. 1998, Barnhardt 2005, Nicol et al. 2010). The Alaska Rural Systemic Initiative (AKRSI), established in 1994, was one of the first and most significant examples of an initiative working to integrate knowledge systems to benefit all students of Alaska, not just Alaska Natives. AKRSI's "purpose was to systematically document Indigenous knowledge systems of Alaska Native people and develop instructional practices that appropriately integrated Indigenous knowledge and ways of knowing into all aspects of education" (Barnhardt 2013:1). In part born from this effort, multiple programs related to combining Indigenous and Western pedagogies with Western mathematical principles are being used in Alaska, with one of the most successful being tied to Yup'ik math modules. Rickard (2005) demonstrated that lessons on how to build a fish rack, when studied in the sixth grade, resulted in higher test scores among those who participated in the 'math in a cultural context" module than among the control group, and Alaska Native youths also scored higher than the control group.

Schools can facilitate students' capacity to understand complexity and respond with flexibility to challenging situations at the individual level. They also can develop students' capacities to envision and imagine alternate futures through the use of simulations and scenarios to explore possible outcomes across all disciplines employing collaboration and technology (Mietzner and Reger 2005, Tidball and Krasny 2011, Jones et al. 2012). This in turn can enhance community resilience because of the vital role played by rural schools. In fact, studies indicate the power of using the community as the curriculum (Haas and Nachtigal 1998, Johns et al 2000). A recent example that ties together the threads of risk reduction, community resilience, public schools as community hubs, and innovative SES governance is the case of Tok, Alaska, a village of approximately 1200 people located on the Alaska Highway. In 2008, after decades of intense wildland fire activity threatening Tok, the community undertook a major effort to thin the stands of black spruce surrounding its buildings. The village is unincorporated, meaning that it has no borough or municipal governments, has high unemployment (a large majority of the workforce is unemployed in some seasons), and the cost of energy to heat buildings is high, with heating oil costing $>\$ 1.06 /$ L(USD). Through a series of community meetings, it was decided to thin trees around the school first. Through strong leadership, a plan was developed that tied the thinning of stands of trees to heating the school (Hermanns 2008). With help from a state grant, the school purchased a biomass boiler to convert the trees into heat, and by 2013, the school district was saving \$350,000 USD annually on electricity and heating costs (Hillman 2014). The energy savings went into hiring local people to thin trees and train to become firefighters. Biomass now also heats a commercial greenhouse growing vegetables to feed the school's students, and the school has been able to hire a music teacher and a counselor (Hillman 2014). The entire infrastructure is on the school grounds. Good forestry and "fire-wise" practices are important concepts in the school curriculum. The greenhouse continues to be a source of learning around indoor agricultural practices and nutrition, and has demonstrated the school's willingness to experiment and innovate (Hillman 2014).

Nonetheless, the challenges and obstacles that rural school systems face in implementing innovations to curriculum and school systems are numerous and nearly monolithic. There is no comprehensive curriculum in use in remote, largely Indigenous, school systems that is integrative and not entirely standards based. The school system works from the top-down to instill consistency and equality across the state educational system. This methodology becomes problematic in that the United States and Alaska are complex systems with a multitude of perspectives and environments in which one-size-fits-all does little to recognize change or the adaptiveness an Arctic SES might require. School as a form of governance with the inclusion of local input is especially important in cases like the rural Arctic, whose communities do not look much like the communities where the rules or guiding principles are developed and enacted (e.g., Washington, D.C., USA; Ottawa, Canada). 
There is no single set of key factors in rural Alaska that impedes the development of resilience-based teaching practices in adaptation-oriented school systems, just as there is no uniform list of resilience practices that can create adaptive schooling across the Arctic. However, the two major current impediments stem from a suite of interactions of federal and state policies tied to No Child Left Behind (NCLB) since 2000 (McDonnell 2005) and high school personnel turnover. The NCLB interactions affect English language learners (Menken 2006), exacerbate economic and racial inequalities (Darling-Hammond 2007, Hursh 2007), and antagonize local community priorities (Goetz 2005). These combine to hinder the enactment of more culturally sensitive, place-based, linguistically flexible, Indigenous, resilience-based, and rurally focused school programs. In fact, Alaska received a waiver in 2013 to opt out of the major provisions of NCLB as the state develops its own system of student performance to "incorporate data that includes but goes beyond test scores to present a more accurate picture of the health of our schools across the state" (Alaska Department of Education and Early Development 2013:1). This is an example of a state that has significant rural and Indigenous populations recognizing that its educational system can create a more holistic process of assessing student success. Clearly it is not only Alaska that sees the current system as unfit: currently at least 36 other states have opted out. Furthermore this response demonstrates the resistance coming from lower levels of governance to increase community input and better address needs from students' learning perspectives. Combined with national regulations, another feature of remote schooling is high teacher and administrative turnover that destabilizes educational pathways. Recruiting and retaining school personnel has become a vital and pressing concern because rural districts average 20\%/yr turnover (Hill and Hirshberg 2013). High personnel turnover significantly reduces the ability to develop locally grounded resilience curriculum and stable community partnerships. Enhancing the recruitment and training of Alaskan or Arctic Alaskan teachers and administrators will positively affect the concerns, in particular, those of the National Indian Education Association, for the need for "culturally based education as it relates to the development of culturally appropriate education pedagogy and curriculum that reflects the social cultural and linguistic heritage of the Native communities" (Beaulieu et al. 2005:5).

Additionally, many rural school sites in Alaska face dwindling populations of students; at $<10$ students, a school is closed altogether. Indigenous students drop out at higher rates and demonstrate lower achievement on standardized measures than their peers (Hirshberg et al. 2014). These schools also struggle to offer the breadth and depth of educational opportunities that their larger and urban counterparts offer students. Two other consequential obstacles to sustaining educational change in rural Alaska are inconsistency of leadership at all levels and funding of school programs. Such system-wide factors provide opportunities for change, innovation, and experimentation upon which resilience is constructed, but a consistent will to address them has yet to be established with durable funding.

\section{CONCLUSION}

Schools can be and have been the heart of community activism, action, and collaboration. Because schools in rural Alaska have often been in place for decades, have some dedicated funding, persist in providing routinized schedules, have the backing of multiple levels of government, and serve as community touchstones that offer stability in a rapidly changing socialecological environment. Public schools have the capacity to contribute to their communities when they have leaders and people in place who are interested (Johns et al. 2000) in the fruitful combination of student success through learning via resilience and broader community-wide engagement. Schools offer an approach of governance that has the power of action in communities. In particular, this can be the case when there is a vacuum of coordinated governance from other sources in a community. Often in village and rural communities, where climate, environmental, and socioeconomic changes are having the greatest effects, the public school could be a haven for innovation and deliberation as a stable, functional, social institution. Although currently mostly externally controlled, schools can become co-managers in a community's future, rather than reactive forces to standardized policies from remote locations.

The formalization of co-management between state and community requires a deeper and more effective role for communities, including their educational systems, in this partnership. As the example of Tok demonstrates, schools are important to their communities and can be deeply connected to ecosystem services. If this partnership is taken seriously, schools could serve as sources of resilience for the local SES to fall back on in times of volatility or uncertainty. As students are trained in adaptive strategies within the organization of the school, they are more likely to carry those strategies into their work, home, and daily existence in the SES of the community. In addition, schools can be the settings where scenarios or decision-making exercises might be played out with lesser stakes, fostering experimentation. In other words, schools could facilitate linkages among village populations, agencies, Alaska Natives, scholars, and others to develop individuals and organizations as advocates for many forms of resilience: ecological, economic, cultural, and individual or student-learning resilience. A new focus on problem solving in schools and preparing students to use knowledge flexibly is in fact creating more resilient individuals. It presents them with suites of knowledge about subjects, which they can apply to various problems in life. This is resilience thinking generally, prior to demonstrating resilience-enhanced outcomes more specific to environmental problems. Education also promotes socialenvironmental resilience through entraining young people in attitudes and skills tied to stewardship practices so that the youth of today can make informed decisions about their environments into the future. These practices can occur in both Western and Indigenous educational systems. Schools as representative microcosms of the macrocosms at large are uniquely poised to explore decision making, scenario development, and collaboration in a way that could inform the system on a larger geographic and temporal scale. The potential influence of schools and education as future powerful agents of resilience and transformation is great.

Why would we benefit in thinking about schools as a form of governance? The approach is straightforward and allows us to think more systematically about the systems governing us and our interactions with the environment. This approach has the capability to produce governance that is resilience based and 
sustainability based around strategies that foster problem solving, critical thinking, and resilience, and respects both TEK and innovation. If we can recognize that we govern through our school systems, maybe we will have a better chance of positively transforming Arctic SESs, schools, and students.

Responses to this article can be read online at: http://www.ecologyandsociety.org/issues/responses. $\mathrm{php} / 7757$

\section{Acknowledgments:}

This research was supported by National Science Foundation grant "IGERT: Global-Local Interactions: Resilience and Adaption of Social-Ecological Systems in a Rapidly Changing North" (grant 0654441). The views expressed here are those of the author and do not represent those of the National Science Foundation. I thank A. L. Lovecraft, T. Chapin, and G. Kofinas for helpful comments on an earlier version of the manuscript.

\section{LITERATURE CITED}

Alaska Department of Education and Early Development, M. 2013. Alaska receives No Child Left Behind waiver. [press release] May 20, 2013. State of Alaska Department of Education and Early Development, Juneau, Alaska, USA. [online] URL: https:// education.alaska.gov/akaccountability/esea/waiver_release_may2013. pdf.

Arctic Council. 2013. Arctic resilience interim report 2013. Arctic Council, Stockholm, Sweden. [online] URL: http://www.seiinternational.org/mediamanager/documents/Publications/ ArcticResilienceInterimReport2013-HighRes.pdf.

Arctic Governance Project. 2010. Arctic governance in an era of transformative change: critical questions, governance principles, ways forward. Arctic Governance Project, Tromsø, Norway. [online] URL: http://www.arcticgovernance.org/agp-report-andaction-agenda.156784.en.html.

Arctic Monitoring and Assessment Programme. 2012. Arctic climate issues 2011: changes in arctic snow, water, ice and permafrost. SWIPA 2011 Overview Report. Arctic Monitoring and Assessment Programme, Oslo, Norway. [online] URL: $\underline{\text { http:// }}$ www.amap.no/documents/download/2267.

Barnhardt, C. 2001. A history of schooling for Alaska Native people. Journal of American Indian Education 40(1):1-30.

Barnhardt, R. 1981. Culture, community and the curriculum. Center for Cross Cultural Studies, University of Alaska, Fairbanks, Alaska, USA. [online] URL: http://www.ankn.uaf. edu/curriculum/Articles/RayBarnhardt/CCC.html.

Barnhardt, R. 2005. Indigenous knowledge systems and Alaska Native ways of knowing. Anthropology and Education Quarterly 36(1):8-23. http://dx.doi.org/10.1525/aeq.2005.36.1.008

Barnhardt, R. 2013. Indigenous education renewal in rural Alaska. Pages 11-20 in J. Reyhner, J., Martin, L. Lockard, and W. S. Gilbert, editors. Honoring our children: culturally appropriate approaches to indigenous education. Northern Arizona University, Flagstaff, Arizona, USA. [online] URL: http://jan.ucc.nau.edu/ jar/HOC/HOC-2.pdf.

Beaulieu, D., L. Sparks, and M. Alonzo. 2005. Preliminary report on No Child Left Behind in Indian country. National Indian Education Association, Washington, D.C., USA. [online] URL: http://www.niea.org/data/files/policy/nieanclbpublication.pdf.

Benard, B. 1995. Fostering resilience in children: ERIC digest. ED386327. ERIC Clearinghouse on Elementary and Early Childhood Education, Urbana, Illinois, USA. [online] URL: http://eric.ed.gov/PDFS/ED386327.pdf.

Bergstrom, A., L. Miller Cleary, and T. D. Peacock. 2003. The seventh generation: Native students speak about finding the good path. ED 472385. ERIC Clearinghouse on Rural Education and Small Schools, Charleston, West Virginia, USA. [online] URL: http://files.eric.ed.gov/fulltext/ED472385.pdf.

Berkes, F., J. Colding, and C. Folke. 2000. Rediscovery of traditional ecological knowledge as adaptive management. Ecological Applications 10(5):1251-1262. http://dx.doi. org/10.1890/1051-0761(2000)010[1251:roteka]2.0.co;2

Bohensky, E. L., and Y. Maru. 2011. Indigenous knowledge, science, and resilience: What have we learned from a decade of international literature on "integration"? Ecology and Society 16 (4): 6. http://dx.doi.org/10.5751/es-04342-160406

Coleman, J. S. 1961. Comment on three "climate of opinion" studies. Public Opinion Quarterly 25(4):607-610. http://dx.doi. org/10.1086/267056

Comber, B. 2013. Schools as meeting places: critical and inclusive literacies in changing local environments. Language Arts 90 (5):361-371.

Darling-Hammond, L. 2007. Race, inequality and educational accountability: the irony of 'No Child Left Behind'. Race Ethnicity and Education 10(3):245-260. http://dx.doi. org/10.1080/13613320701503207

Darnell, F., and A. Hoëm. 1996. Taken to extremes: education in the far North. Scandinavian University Press, Oslo, Norway.

Dewey, J. 1897. My pedagogic creed. E. L. Kellogg and Company, New York, New York, USA.

Eliot, T. H. 1959. Toward an understanding of public school politics. American Political Science Review 53(4):1032-1051. http://dx.doi.org/10.2307/1952073

Folke, C., J. Colding, and F. Berkes. 2002. Synthesis: building resilience and adaptive capacity in social-ecological systems. Pages 352-387 in F. Berkes, J. Colding, and C. Folke, editors. Navigating social-ecological systems: building resilience for complexity and change. Cambridge University Press, Cambridge, UK. http://dx.doi.org/10.1017/cbo9780511541957.020

Gadgil, M., F. Berkes, and C. Folke. 1993. Indigenous knowledge for biodiversity conservation. Ambio 22(2-3):151-156.

Gerlach, S. C., P. A. Loring, A. Turner, an D. E. Atkinson. 2011. Food systems, environmental change, and community needs in rural Alaska. Pages 111-133 in A. L. Lovecraft and H. Eicken, 
editors. North by 2020: perspectives on Alaska's changing socialecological systems. University of Alaska Press, Fairbanks, Alaska, USA.

Goetz, S. J. 2005. Random variation in student performance by class size: implications of NCLB in rural Pennsylvania. Journal of Research in Rural Education 20(13):1-8. [online] URL: http:// jrre.vmhost.psu.edu/wp-content/uploads/2014/02/20-13.pdf.

Greenstein, F. I. 1960. The benevolent leader: children's images of political authority. American Political Science Review 54 (4):934-943. http://dx.doi.org/10.2307/1952644

Gruenewald, D. A. 2003. Foundations of place: a multidisciplinary framework for place-conscious education. American Educational Research Journal 40(3):619-634. http://dx. doi.org/10.3102/00028312040003619

Haas, T., and P. Nachtigal. 1998. Place value: an educator's guide to good literature on rural lifeways, environments, and purposes of education. ED420461. ERIC Clearinghouse on Rural Education and Small Schools, Charleston, West Virginia, USA.

Henderson, N. 2013. Havens of resilience. Educational Leadership 71(1):22-27. [online] URL: http://www.ascd.org/publications/ educational-leadership/sept13/vol71/num01/Havens-of-Resilience. aspx.

Hermanns, J. 2008. Hazard fuel reduction and bio-energy projects coexist in the community of Tok. Division of Forestry, Alaska Department of Natural Resources, Anchorage, Alaska, USA. [online] URL: http://forestry.alaska.gov/pdfs/08TokFireMitigationSchoolProject.pdf.

Hill, A., and D. Hirshberg. 2013. Alaska teacher turnover, supply, and demand: 2013 highlights. Center for Alaska Education Policy Research, University of Alaska, Anchorage, Alaska, USA. [online] URL: http://www.alaskateacher.org/downloads/2013TeacherTurnover.pdf.

Hillman, A. 2014. Tok biomass boiler heats school, funds music teacher. Alaska Public Media. KSKA, Anchorage. 11 February 2014. Anchorage, Alaska, USA. Print and radio broadcast. [online] URL: http://www.alaskapublic.org/2014/02/11/tokbiomass-boiler-heats-school-funds-music-teacher/.

Hirshberg, D., A. Petrov, R. Barnhardt, P. Cavin, S. Gearheard, A. Hodgkins, J. H. Keskitalo, G. Maheux, H. E. McGregor, P. K. K. Olsen, V. Paul, R. O. Rasmussen, A. Rautio, A. Rönkä, and E. Uitangak. 2014. Education and human capital. Pages 347-396 in J. N. Larsen and G. Fondahl, editors. Arctic human development report: regional processes and global linkages. Volume II (20102014). Nordic Council of Ministers, Copenhagen, Denmark. http://dx.doi.org/10.6027/TN2014-567

Hirshberg, D., and S. Sharp. 2005. Thirty years later: the longterm effect of boarding schools on Alaska Natives and their communities. Institute of Social and Economic Research, University of Alaska, Anchorage, Alaska, USA. [online] URL: http://www.iser.uaa.alaska.edu/Publications/boardingschoolfinal. pdf.

Hunn, E. S., D. R. Johnson, P. N. Russell, and T. F. Thornton. 2003. Huna Tlingit traditional environmental knowledge, conservation, and the management of a "wilderness" park.
Current Anthropology 44(S5):S79-S103. [online] URL: http:// www.jstor.org/stable/10.1086/377666

Hursh, D. 2007. Assessing No Child Left Behind and the rise of neoliberal education policies. American Educational Research Journal 44(3):493-518. http://dx.doi.org/10.3102/0002831207306764

Jenkins-Smith, H. C., D. Nohrstedt, C. M. Weible, and P. A. Sabatier. 2014. The advocacy coalition framework: foundations, evolution, and ongoing research. Pages 183-224 in P. A. Sabatier and C. M. Weible, editors. Theories of the policy process. Third edition. Westview Press, Boulder, Colorado, USA.

Jester, T. E. 2002. Healing the "unhealthy Native": encounters with standards-based education in rural Alaska. Journal of American Indian Education 41(3):1-21.

Jimerson, L. 2006. The hobbit effect: why small works in public schools. Rural Trust Policy Brief Series on Rural Education. Rural School and Community Trust, Arlington, Virginia, USA. [online] URL: $\underline{\text { http://files.eric.ed.gov/fulltext/ED497985.pdf. }}$

Johns, S., S. Kilpatrick, I. Falk, and B. Mulford. 2000. School contribution to rural communities: leadership issues. CRLRA Discussion Paper D1/2000. Center for Research and Learning in Regional Australia, University of Tasmania, Launceston, Australia.

Jones, A., C. Buntting, R. Hipkins, A. McKim, L. Conner, and K. Saunders. 2012. Developing students' futures thinking in science education. Research in Science Education 42(4):687-708. http://dx.doi.org/10.1007/s11165-011-9214-9

Kaplan, H. B. 2002. Toward an understanding of resilience: a critical review of definitions and models. Pages 17-83 in M. D. Glantz and J. L. Johnson, editors. Resilience and development: positive life adaptations. Kluwer Academic/Plenum Publishers, New York, New York, USA. http://dx.doi.org/10.1007/0-306-47167-1 3

Kawagley, A. O. 1995. A Yupiaq worldview: a pathway to ecology and spirit. Waveland Press, Prospect Heights, Illinois, USA.

Kawagley, A. O., and R. Barnhardt. 1999. Education indigenous to place: Western science meets Native reality. Pages 117-140 in G. A. Smith and D. R. Williams, editors. Ecological education in action: on weaving education, culture, and the environment. State University of New York Press, Albany, New York, USA.

Key, V. O. Jr. 1961. Public opinion and American democracy. Knopf, New York, New York, USA.

Kofinas, G. P., and F. S. Chapin III. 2009. Sustaining livelihoods and human well-being during social-ecological change. Pages 55-75 in F. S. Chapin III, G. P. Kofinas, and C. Folke, editors. Principles of ecosystem stewardship: resilience-based natural resource management in a changing world. Springer, New York, New York, USA. http://dx.doi.org/10.1007/978-0-387-73033-2_ 3

Krupnik, I., and D. Jolly. 2002. The Earth is faster now: Indigenous observations of Arctic environmental change. Arctic Research Consortium of the United States, Fairbanks, Alaska, USA.

Lebel, L., J. M. Anderies, B. Campbell, C. Folke, S. HatfieldDodds, T. P. Hughes, and J. Wilson. 2006. Governance and the capacity to manage resilience in regional social-ecological system. Ecology and Society 11(1): 19. [online] URL: http://www. ecologyandsociety.org/vol11/iss1/art19/. 
Lemos, M. C., and A. Agrawal. 2006. Environmental governance. Annual Review of Environment and Resources 31:297-325. http:// dx.doi.org/10.1146/annurev.energy.31.042605.135621

Lemos, M. C., and A. Agrawal. 2009. Environmental governance and political science. Pages 69-97 in M. A. Delmas and O. R. Young, editors. Governance for the environment: new perspectives. Cambridge University Press, Cambridge, UK. http://dx.doi. org/10.1017/cbo9780511627170.005

Lipka, J., G. V. Mohatt, and the Ciulistet Group. 1998. Transforming the culture of schools: Yup'ik Eskimo examples. Lawrence Erlbaum Associates, Mahwah, New Jersey, USA.

Litt, E. 1963. Civic education, community norms, and political indoctrination. American Sociological Review 28(1):69-75. http:// dx.doi.org/10.2307/2090460

Lovecraft, A. L., and H. Eicken, editors. 2011. North by 2020: perspectives on Alaska's changing social-ecological systems. University of Alaska Press, Fairbanks, Alaska, USA.

Maffi, L. 2005. Linguistic, cultural, and biological diversity. Annual Review of Anthropology 34:599-617. http://dx.doi. org/10.1146/annurev.anthro.34.081804.120437

Maffi, L. 2007. Biocultural diversity and sustainability. Pages 267-278 in J. Pretty, A. S. Ball, T. Benton, J. S. Guivant, D. R. Lee, D. Orr, M. J. Pfeffer, and H. Ward, editors. The Sage handbook of environment and society. Sage, Thousand Oaks, California, USA. http://dx.doi.org/10.4135/9781848607873.n18

McDonnell, L. M. 2005. No Child Left Behind and the federal role in education: evolution or revolution? Peabody Journal of Education 80(2):19-38. http://dx.doi.org/10.1207/s15327930pje8002_2

McGregor, H. E. 2010. Inuit education and schools in the eastern Arctic. UBC Press, Vancouver, Canada.

McLean, D. L. 1997. Rural Alaska Native perceptions of cultural transmission: implications for education. Journal of American Indian Education 36(3):16-26.

Menken, K. 2006. Teaching to the test: how No Child Left Behind impacts language policy, curriculum, and instruction for English language learners. Bilingual Research Journal 30(2):521-546. http://dx.doi.org/10.1080/15235882.2006.10162888

Mietzner, D., and G. Reger. 2005. Advantages and disadvantages of scenario approaches for strategic foresight. International Journal of Technology Intelligence and Planning 1(2):220-239. http://dx.doi.org/10.1504/IJTIP.2005.006516

Millennium Ecosystem Assessment. 2005. Ecosystems and human well-being: synthesis. Island Press, Washington, D.C., USA. [online] URL: http://www.millenniumassessment.org/documents/ document.356.aspx.pdf.

Miller, B. A. 1995. The role of rural schools in community development: policy issues and implications. Journal of Research in Rural Education 11(3):163-172. [online] URL: http://jrre. vmhost.psu.edu/wp-content/uploads/2014/02/11-3 3.pdf.

Nicol, C., J. Archibald, and J. Baker. 2010. Investigating culturally responsive mathematics education. Canadian Council on Learning and University of British Columbia, Vancouver, Canada. [online] URL: http://www.ccl-cca.ca/pdfs/FundedResearch/201009Nico$\underline{\text { ArchibaldBakerFullReport.pdf. }}$
Nicol, C., J. Archibald, and J. Baker. 2013. Designing a model of culturally responsive mathematics education: place, relationships and storywork. Mathematics Education Research Journal 25 (1):73-89. http://dx.doi.org/10.1007/s13394-012-0062-3

Olsson, P., C. Folke, and F. Berkes. 2004. Adaptive comanagement for building resilience in social-ecological systems. Environmental Management 34(1):75-90. http://dx.doi.org/10.1007/ $\underline{\mathrm{s} 00267-003-0101-7}$

Orr, D. W. 1994. Earth in mind: on education, environment, and the human prospect. Island Press, Washington, D.C., USA.

Ostrom, E., M. Cox, and E. Schlager. 2014. An assessment of the institutional analysis and development framework and introduction of the social-ecological systems framework. Pages 267-306 in P. A. Sabatier and C. M. Weible, editors. Theories of the policy process. Third edition. Westview Press, Boulder, Colorado, USA.

Patterson, F. 1960. High schools for a free society. Free Press, Glencoe, Illinois, USA.

Popkewitz, T. S. 1998. Dewey, Vygotsky, and the social administration of the individual: constructivist pedagogy as systems of ideas in historical spaces. American Educational Research Journal 35(4):535-570. http://dx.doi.org/10.3102/0002$\underline{8312035004535}$

Raffan, J. 1993. The experience of place: exploring land as teacher. Journal of Experiential Education 16(1):39-45. http://dx.doi. org/10.1177/105382599301600109

Rasmussen, D. 2001. Qallunology: a pedagogy for the oppressor. Canadian Journal of Native Education 25(2):105-116.

Rickard, A. 2005. Constant perimeter, varying area: a case study of teaching and learning mathematics to design a fish rack. Journal of American Indian Education 44(3):80-100. [online] URL: https://jaie.asu.edu/sites/default/files/443_2005 5 rickard. pdf.

Salant, P., and A. Waller. 1998. What difference do local schools make? A literature review and bibliography. ED437260. Prepared for the Annenberg Rural Challenge Policy Program. ERIC Clearinghouse on Rural Education and Small Schools, Charleston, West Virginia, USA. [online] URL: http://files.eric. ed.gov/fulltext/ED437260.pdf.

Seidman, E. 1986. Justice, values, and social science: unexamined premises. Pages 235-258 in E. Seidman and J. Rappaport, editors. Redefining social problems. Springer, New York, New York, USA. http://dx.doi.org/10.1007/978-1-4899-2236-6_14

Semken, S. 2005. Sense of place and place-based introductory geoscience teaching for American Indian and Alaska Native undergraduates. Journal of Geoscience Education 53(2):149-157. [online] URL: http://www.nagt.org/nagt/ige/abstracts/mar05. html\#v53p149.

Shaull, R. 1993. Foreword. In P. Freire. Pedagogy of the oppressed. Second edition. Continuum Publishing, New York, New York, USA.

Sobel, D. 2005. Place-based education: connecting classrooms and communities. Orion Society, Great Barrington, Massachusetts, USA. 
Spellman, K. V. 2015. Educating for resilience in the North: building a toolbox for teachers. Ecology and Society 20(1): 46. http://dx.doi.org/10.5751/ES-07243-200146

Tidbal, K. G., and M. E. Krasny. 2011. Toward an ecology of environmental education and learning. Ecosphere 2(2): 21. http:// dx.doi.org/10.1890/es10-00153.1

Todal, J. 1999. Minorities with a minority: Language and the school in the Sámi areas of Norway. Pages 124-136 in S. May editor. Indigenous community-based education. Multilingual Matters, Clevedon, UK.

Turner, N. J., M. B. Ignace, and R. Ignace. 2000. Traditional ecological knowledge and wisdom of aboriginal peoples in British Columbia. Ecological Application 10(5):1275-1287. http://dx.doi. org/10.1890/1051-0761(2000)010[1275:tekawo]2.0.co;2

Varghese, J., N. T. Krogman, T. M. Beckley, and S. Nadeau. 2006. Critical analysis of the relationship between local ownership and community resiliency. Rural Sociology 71(3):505-527. http://dx. doi.org/10.1526/003601106778070653

Walsh, J. 2013. Fourteenth Annual Roger Revelle Commemorative Lecture. Melting ice: What is happening to Arctic sea ice and what does it mean for us? Oceanography 26(2):171-181. http://dx.doi. org/10.5670/oceanog.2013.19

Wamsler, C., E. Brink, and O. Rantala. 2012. Climate change, adaptation, and formal education: the role of schooling for increasing societies' adaptive capacities in El Salvador and Brasil. Ecology and Society 17(2): 2. http://dx.doi.org/10.5751/ es-04645-170202

Wright, A. 2004. Preserving and affirming rural values through the curriculum. Educational Forum 68(1):32-41. http://dx.doi. org/10.1080/00131720308984601

Wright, K. A. 2007. Reenergizing small communities: a vital role for rural schools. Educational Forum 71(4):345-360. http://dx.doi. org/10.1080/00131720709335024

Young, O. R. 1992. The effectiveness of international institutions: hard cases and critical variables. Pages 160-194 in J. N. Rosenau and E.-O. Czempiel, editors. Governance without government: order and change in world politics. Cambridge University Press, Cambridge, UK. http://dx.doi.org/10.1017/cbo9780511521775.008 